\title{
Amalgamation and the Crisis of Governance: The Nigeria Experience
}

\author{
Oluwatobi, O. Adeyemi (Ph.D) \\ Department of Local Government Studies, \\ Obafemi Awolowo University’ Ile- Ife, Nigeria
}

Received: May 1, 2018 Accepted: July 6, 2018 Online published: July 16, 2018

doi:10.5296/jpag.v8i3.13390 URL: https://doi.org/10.5296/jpag.v8i3.13390

\begin{abstract}
This paper deals with the discourse on evolution of Nigerian state and the challenges it poses for actualisation of democratic governance in the polity. The continued crises in the polity and corrupt practices that characterizes Nigerian state overtime reveals a diminishing state of accountability and ethical values which has its foundation in emergence of the Nigerian state. Since the purpose of amalgamation was to protect the British economic interest and to facilitate exploitation of the nation's resources, the Nigerian politician who took over power from the British continued from where they stopped, thereby making the state an instrument to perpetuate corrupt practices of all sorts. The implication of this is the disappearance of democratic values, political decadence and retarded development. Methodologically, the paper adopted a qualitative research technique of data collection through the content analysis of empirical studies conducted by scholars who have made outstanding contributions on the practice of governance within and outside Nigerian political landscape. Against this analytical background, the study analyses the issue of governance vis-a-vis avoidable crises foisted on the polity by the politicians since the commencement of the independence in 1960 and finds out that, the present governance crises in Nigeria had its root in colonialism. The study therefore calls for a resolution among the federating units which must entail a renegotiation of the polity along democratic principles and a total reform of the anti-corruption agencies for effective performance.
\end{abstract}

Keywords: amalgamation, governance, democracy, corruption, colonialism

\section{Introduction}

Given the ethno religious diversity of the various groups that presently constitute modern Nigeria, the amalgamation of southern and Northern Nigeria protectorates by British colonizers in 1914 has been widely referred to by many observers and scholars as a mistake of colonial administration (Akinola, 2013). Nigeria was first and foremost created not for 
Nigeria's diverse ethnic nationalities but as British sphere of geo- political influence and economic interests. According to Akinjide $(2000,2001)$ what the British amalgamated in 1914 was fundamentally the administration of the North and South and not the people of the North and South. The implication of these divisions is that, it reinforce uneven development amongst the various nationalities - especially at the level of education, thereby exacerbating fear of dominion in post-colonial epoch (Abubakar, 2003). This structure sowed the seed of discord in the polity. Notably, Nigeria was in communal stage of development when western capitalism was foisted through colonialism. This changed the mode of production and produced clientele structure and magnetized the polity. Forced labour, taxes and punitive laws or ordinances were employed to achieve these exploitative economic motives. The construction of roads, rails and ports was to facilitate easier evacuation of goods and other resources from the hinterland to the coast (Ezeibe, No Date). This fact is central to understanding the country's government and politics, which have been conditioned and bedevilled by the crisis of governance such as long military rule, political and religion crises, ethnicity, terrorism and corruption since the Nigerian independent.

Nigeria became a Nation-State on January 1, 1914 with the amalgamation of the southern and northern protectorates, after many years of colonial rule, on 1st October, 1960 Nigeria gained its independence from Britain. The first republic was short-lived, ending with the coup d'état of January 15, 1966. Between this period and October 1, 1979 when civilian rule returned, the country was administered by the military. The return to democratic rule ushered in a federal constitution characterized by multi-party, independence of judiciary, separation of powers, among other features. This experience was, however, truncated again by the military intervention on December 31, 1983, and the country remained firmly under military rule until May 29, 1999 when another democratic government was ushered in Nigeria.

The paper therefore, examines of the impact of the historical amalgamation on the Nigerian state. In achieving this stated objective. The paper is segmented into six different sections viz; the introduction, conceptual framework, theoretical framework, evolution of Nigerian state, amalgamation and the crisis of governance in Nigeria and the final part which is conclusion and policy recommendations.

\section{Conceptual Elucidation}

Within the disciplinary circles of social science, the issue of definition of concepts has always been problematic issues. This has been largely due to various orientations and ideological dispositions of respective scholar within the discipline. The concept of governance too is not an exceptional in this regard, that is a why it has attracted the intellectual concern of many renowned and internationally acclaimed scholars who have seriously examine and explain the meaning, genesis and the need for this in the democratic process within the political system. Therefore there is no uniform agreement as to its boundary, scope and purpose.

\section{The Concept of Governance}

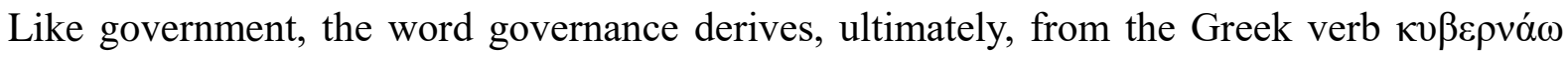
[kubernáo] (meaning to steer, the metaphorical sense first being attested in Plato). In 
above-described sense, however, the term governance was coined as recently as the 1990s by economists and political scientists, and disseminated by institutions such as the UN, IMF and World Bank (Europa, No Date). Conceptually, governance (as opposed to "good" governance) can be defined as the rule of the rulers, typically within a given set of rules. One might conclude that governance is the process by which authority is conferred on rulers, by which they make the rules, and by which those rules are enforced and modified. Thus, understanding governance requires an identification of both the rulers and the rules, as well as the various processes by which they are selected, defined, and linked together and with the society generally (World Bank, No Date). Governance refers to "all processes of governing, whether undertaken by a government, market or network, whether over a family, tribe, formal or informal organization or territory and whether through laws, norms, power or language (Bevir, M. (2013). It relates to processes and decisions that seek to explicate actions grant power and verify performance.

According to Gery Stoker in (Adeyemo and Ihemeje, 2008:20-21), there are five basic theories that can be used to examine and clarify governance. These are the propositions:

1. Government refers to a set of institutions and action that are drawn from but also beyond government.

2. Government identifies the blurring of boundaries and responsibilities for tackling social and economic issues.

3. Governance identifies the power dependence involved in the relations between institutional involved in collective actions.

4. Governance is about autonomous self-governing networks of actors.

5. Governance recognizes the capacity to get things done which does not rest on the power of government to command or use its authority. It sees government as able to use new tools and techniques to steer and guide.

Jega (1999:101), analysed the concept of governance in relations to the person entrusted with political power and authority. According to him, governance involves the following:

1. Responsibility and responsiveness in leadership and in public service

2. Accountability in the mobilisation as well as in the utilisation of resources

3. Discipline, effectiveness and efficiency in handling public as well as personal affairs

4. Selflessness and impartial service to people and

5. Popular participation and empowerment of the people in the conduct and management of their common affairs.

Nonetheless, within this concept of governance, the obvious second question is: What is good governance? Again, the debate on the quality of governance has been clouded by a slew of slightly differing definitions and understanding of what is actually meant by the term. This term will be better appreciated, if will first understand what is 'bad governance'. The 
possibility of bad governance could be said to be what the World Bank had in mind in 1989, when it began to differentiate between good and bad governance.

In fact, the World Bank (1992), identified the features of bad governance as follows:

1. Failure to make a clear separation between what is public and what is private, hence a tendency to divert public resources for private gain;

2. Failure to establish a predictable framework for law and government behaviour in a manner that is conducive to development, or arbitrariness in the application of rules and laws;

3. Excessive rules, regulations, licensing requirement, etc which impede the functioning of markets and encourage rent-seeking.

4. Priorities that are inconsistent with development, thus, resulting in a misallocation of resources

5. Excessively narrow base for, or non-transparent, decision-making.

Therefore, it is imperative at this juncture to examine what good governance is. Typically, it is defined in terms of the mechanisms thought to be needed to promote it (World Bank, No Date). Depending on the context and the overriding objective sought, good governance has been said at various times to encompass: full respect of human rights, the rule of law, effective participation, multi-actor partnerships, political pluralism, transparent and accountable processes and institutions, an efficient and effective public sector, legitimacy, access to knowledge, information and education, political empowerment of people, equity, sustainability, and attitudes and values that foster responsibility, solidarity and tolerance (Ohchr, No Date)

The concept of "good governance" often emerges as a model to compare ineffective economies or political bodies with viable economies and political bodies (Khan, 2004). The concept focuses on the responsibility of governments and governing bodies to meet the needs of the masses as opposed to select groups in society. Because the governments treated in the contemporary world as most "successful" are often liberal democratic states concentrated in Europe and the Americas, those countries' institutions often set the standards by which to compare other states' institutions when talking about governance (Khan, 2004). Along this line, Unescap (No date) highlighted the eight major pillars of good governance as follows:

\section{Participation}

Participation by both men and women is a key cornerstone of good governance. Participation could be either direct or through legitimate intermediate institutions or representatives. It is important to point out that representative democracy does not necessarily mean that the concerns of the most vulnerable in society would be taken into consideration in decision making. Participation needs to be informed and organized. This means freedom of association and expression on the one hand and an organized civil society on the other hand. 


\section{Macrothink}

Rule of Law

Good governance requires fair legal frameworks that are enforced impartially. It also requires full protection of human rights, particularly those of minorities. Impartial enforcement of laws requires an independent judiciary and an impartial and incorruptible police force.

\section{Transparency}

Transparency means that decisions taken and their enforcement are done in a manner that follows rules and regulations. It also means that information is freely available and directly accessible to those who will be affected by such decisions and their enforcement. It also means that enough information is provided and that it is provided in easily understandable forms and media.

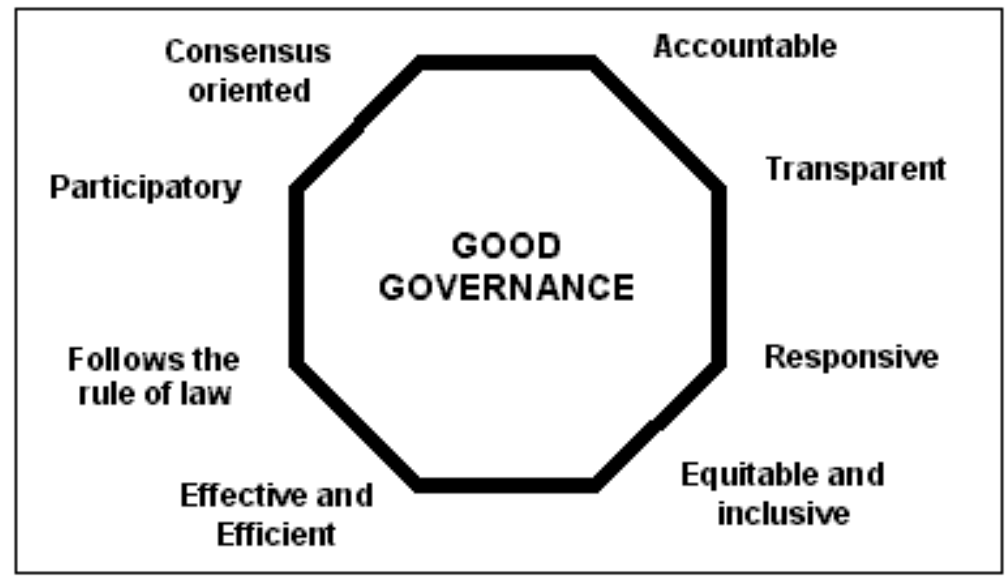

Figure 1. Characteristics of good governance

Source: (Unescap, No Date).

\section{Responsiveness}

Good governance requires that institutions and processes try to serve all stakeholders within a reasonable timeframe.

\section{Consensus Oriented}

There are several actors and as many view points in a given society. Good governance requires mediation of the different interests in society to reach a broad consensus in society on what is in the best interest of the whole community and how this can be achieved. It

Also requires a broad and long-term perspective on what is needed for sustainable human development and how to achieve the goals of such development. This can only result from an understanding of the historical, cultural and social contexts of a given society or community.

\section{Equity and Inclusiveness}

A society's well-being depends on ensuring that all its members feel that they have a stake in it and do not feel excluded from the mainstream of society. This requires all groups, but particularly the most vulnerable, have opportunities to improve or maintain their well-being. 
Effectiveness and Efficiency

Good governance means that processes and institutions produce results that meet the needs of society while making the best use of resources at their disposal. The concept of efficiency in the context of good governance also covers the sustainable use of natural resources and the protection of the environment.

\section{Accountability}

Accountability is a key requirement of good governance. Not only governmental institutions but also the private sector and civil society organizations must be accountable to the public and to their institutional stakeholders. Who is accountable to who varies depending on whether decisions or actions taken are internal or external to an organization or institution. In general an organization or an institution is accountable to those who will be affected by its decisions or actions. Accountability cannot be enforced without transparency and the rule of law (Unescap, No Date).

\section{The Emergence of Nigerian State: A Theoretical Discourse}

The origin of Nigerian state can be understood from the standpoint of force theory. The force theory holds that the state originated in conquest and coercion. It is a consequence of the strong establishing their dominion over the weak, setting them in a specified territory and arrogating to themselves the power of governing (Anifowose, 2008:96; Akindele, et al, 2000:38).

Anifowose (2008:96) reaffirms that, in the later part of the $29^{\text {th }}$ century, some German philosopher argued that force was the most characteristic attribute of the state, that "might made right" and that power has its own justification. Hence it was concerned that physically powerful peoples were the "best and the state as power, was superior to other forms of human associations. The force theory accordingly, has no respect for the natural rights of the citizens and does not approve of any resistance to the act of political authority

Jenks a proponent of this theory posits that, "there is not the slightest difficulty in proving that all political communities of the modern type owes their existence to successful warfare" (Akindele, 2000:38).

However, in line from the above, we could infer that, the emergence of Nigerian State could be trace to force theory. According to Obasanjo cited in (Kolawole, 2004:51), Nigeria is a product of colonial creation. This is because until 1900, the land mass known today as Nigeria existed as a number of independent and sometime hostile national states with linguistic and cultural differences. It is important to state that the Nigerian state falls into the category of nations which Thomas Hobbes labelled as 'Commonwealth by acquisition'. The implication of this is that Nigerian state is a product of force union. The historical circumstances of her emergence make her an amalgam of divergent people with divergent languages, culture, values and beliefs. (Kolawole, 2004:49). Nigeria could be described as a product of British suzerainty, forcefully forged from varieties of ethnic sub-nationalities (Adetoye, 2004:342). The colonialist amalgamated the southern and the northern protectorate 
in the year 1914 without a due consultation with her people. Hence, Nigeria was a British intension to aid economic exploitation of her resources. The state imposed on Nigerians by colonialist differed widely from the orthodox state in Europe where the power of the state was employed to mediate the interests of the contending classes and in the end to impose the domination of one class over the other. The colonial state was parasitic, exploitative, despotic and dictatorial (Agagu, 2004). Nnoli (2000:6) put this better perspective as thus:

Under the circumstances, the colonial state structure was authoritarian, anti-democratic, domineering and repressive. In pursuit of its colonial mission, it intervened anywhere and any how it deemed fit. Expeditionary forces crush revolt and dissent physically and violently. The state manipulated ethnicity, religion, race, patriarchy and locality (region) to divide African populations. Initially, there was no attempt to build a democratic consensus over the issues of public concern. In the pursuit of the colonialist, justice equality, fair play and transparent governance assumed secondary importance. The virtual monopoly of the African country's resources by the colonial state relative to other social organisations compounded the undemocratic character of the state structure.

Therefore, a typical colonial state in Africa was a kleptomania edifice concentrating all the social goods in its hand and establishing a political and administrative structure that promotes exploitation which has resulted to governance crisis in most African countries.

\section{The Evolution of Nigerian State}

Prior to amalgamation, the pre-colonial societies in Nigeria were made up of empires, a caliphate, kingdoms, chiefdoms, city states and villages with ruler that exercise absolute authority over them as in the case of empire or kingdom in the northern region, the Oba in the West, whose power can be checkmated by constituted authority and the Igbo society in the East with its republic and egalitarian status. The initial penetration of the British Government left Nigeria in three separate entities, that is, the Colony of Lagos, the Northern Protectorate and Southern Protectorate. These three areas were followed by distinctive boundaries but issues relating to boundary demarcations and delimitation often caused friction. The British Government became dissatisfied with the system of maintaining three separate administrative units with boundaries. It was as a result of this that the British Government embarked on the amalgamation of the country so that the different entities could be united (Chiamogu, et al, 2011).

Officially, Nigeria became a state on January 1, 1914 after the amalgamation of the southern and northern protectorates. After many years of colonial rule, the country became independent on 1st October, 1960. The first republic was short-lived, ending with the coup d'état of January 15, 1966. Between this period and October 1, 1979 when civilian rule returned, the country was administered by the military. The return to democratic rule ushered in a federal constitution characterized by multi-parties, independence of judiciary, separation of powers, among other features. This experience was, however, truncated again by the 
military intervention in Nigerian politics on December 31, 1983, and the country had remained under military rule until May 29, 1999 when another democratic government began which ushers in Olusegun Obasanjo as the president of the federal republic of Nigeria.

\section{Amalgamation and the Crisis of Governance in Nigeria: A Review}

The origin and motive of establishing the Nigerian state and its path and orientation of development have altogether resulted in the current negative and warped state of development. The whole essence of Berlin Conference of 1884/85 and effective occupation of African continent by the colonialist was the integration of Africa into the world capitalist system for the sole benefit of the conquerors (Agagu, 2004:3). Hence, the Nigerian State given its origin and nature has never been conducive for democracy. This is because it was a state created by force, dominion and imposition, rather than by consensus. The Lugard's system of indirect rule not only compartmentalized the diverse nationalities and ethnic groups (divide and rule tactics) but also provoke crises amongst the Igbo nationality by inventing the institution of "Warrant Chief". Thus colonialism not only exacerbated ethnic based identities, control and exploitation but as Mamdani (1996) asserts, it marshalled authoritarian possibilities in indigenous culture. From a historical perspective, the patrimonial and prebendalist approach to the exercise of political power in contemporary Nigeria in could be traced to the antecedents of the Lugardian colonialist state project. From the foregoing, it could be seen that colonialism laid a faulty foundation for good governance in Nigerian state.

According to Agagu (2004) the nationalist movement at the forefront of decolonization and pursuit of democracy was basically made up of disparate groups such as a network of nationality ethnic groups, religious groups, educated elites among others. The basic issue rallying them together was their opposition to colonial rule having been denied participation in the colonial enterprise. Unfortunately, in spite of their alliance against the colonialists, their relationship was still marked by tension and conflict. The mobilization of ethnic identities for the purpose of capturing political power became an easy instrument of manipulation by the educated elite in quest for power. Thus, political parties which emerged in the First republic (1960-1966) were basically anchored around ethnic and regional 'homeland'. While the Northern People Congress (NPC) dominated the Hausa-Fulani North; the Action Group (AG) held on to Yoruba South-West. The National Council of Nigerian Citizens (NCNC) on its part consolidated its hold on the Igbo South-East. It was this tripodal ethno-regional politics coupled with instances of violence, thuggery, election rigging and generalised underdevelopment that led to the ultimate demise of the First Republic and Nigeria's descent into civil war between 1976-1970 (Abubakar, 2003). Ake (1996:4) captured the reality when depicted thus:

As the prospect for independence improved, the solidarity of the movement grew weaker and competition between its component units became more intense. Although the members of the coalition fought against the colonial power; they worried about the enormous power they were trying to wrestle from it, power they could not entrust to any one of them or even share in a way that could reduce political anxiety. 
The normative, institutional, and ideological mechanisms that would have made this power subject to constitutional constraints and accountability did not exist ... by time independence was achieved in the early 1960s, the centrifugal tendencies had grown strong enough... to threaten not only the transition to independence but more importantly the political viability of the new government.

Hence, during the decolonization phase, the elite were only interested in gaining independence from the colonialist. However, seeds of the authoritarian and patrimonial culture planted during the colonial epoch and the decolonization phase matured at independence (Abubakar, 2003:86). Bagura (1988) rightly capture the scenario as thus:

The struggle for power intensified often at the expense of the provision of the liberal democratic ideals of the constitution... The violence that attended the election of 1964 and 1965, the acrimony over the census of 1963, the inability of the leading parties to recognise the genuine rights of the minorities in their respective areas (culminating for instance, in the Tiv riots) made the military coup of January 1966 and the subsequent civil war... inevitable. The democratic question had ceased to be a dominant project of the national bourgeoisies

Political activities heralding independence and even political independence on October 1960 did not engender harmony or unity. As Ihonvbere (1996:13) obverses, political independence did not alter the North-South divide, the appropriation of the political processes by few 'enlighten' elites across the country, religions and regional difference already politicised as well as political tensions within and between regions. The observable situation was that later in the First Republic, the political elites of the West could not maintain law and order, while those of the North, could not guarantee the safety and property of individuals and that forces of disintegration were going to override the forces of stability and peace. Politics during first republic was thus chaotic and turbulent (Ihonvbere 1996).Thus, the struggle for power intensified, often at the expense of the provisions of the liberal democratic ideals of the constitution. The violence that attended the election of 1964 and 1965, the acrimony over census of 1963, the inability of the leading parties to recognise the genuine rights of the minorities in their respective areas (culminating for instance, in the Tiv riots) made the military coup of January 1966 and the subsequent civil war inevitable (Abubakar, 2003). Ajayi (2004:279) reported the scenario at the Western Nigeria as thus:

The 1964 electoral crisis marked the watershed in the nation's political history. The crisis was originally a Western regional affair between Obafemi Awolowo and Ladoke Akintola who had been pitched by intra-party squabbles in the Action Group political party. The squabbles led to leadership contestations between the two political giants. The Tafawa Balewa's regime seized the opportunity to penetrate the West that had earlier seemed impenetrable politically by 
central ruling party, the Northern People Congress (NPC). The federal government under Balewa's regime which gave its support to the Akintola faction allegedly rigged the election in favour of Akintola, who had form official coalition with the ruling party in the region. The political and electoral manipulation eventually not only sustained the crisis in the region but equally escalated it to a situation of national crisis which eventually became part of the problems that culminated in the first military coup in 1966 which terminated the First Republic, and eventually led to the civil war

From the foregoing analysis, it could be noticed that the problem with the Lugardian 'amalgamation' was not only because of its false historical premise - even rooted as it were in the divide-and-rule strategy of British imperialism but that even most importantly, the elite who inherited power retained the centralising logic and structures of the colonial state along with its coercive, predatory and resources was exacerbated not only by the preoccupation of the elite with issues of post-colonial project, 'national unity'/ integration, but also the subsequent dominance of the military as key actors in the contestation for political power (Abubakar, 2003).The Nigerian army, like those of other British colonies in Africa, was originally conceived as a mechanism for subjugation of the people to the will of the foreign colonizer. As a tool in the hands of the foreigners to plunder, the colonial state was violent and predatory; it represented not the sovereignty of the state apparatus that was bequeathed to Nigerians as a new independent and sovereign state in October 1960 (Fawole, 2003).

Historically, crisis of governance especially large scale corruption began with the advent of military rule in Nigeria in 1966. There were abysmal looting of the Nigeria treasury as well as the bastardazation of public institutions and civil morality by successive military administrations, especially those of Ibrahim Babaginda, Sani Abacha and Abdulasalaam Abubakar. Succeeding military regimes have been more corrupt than those they topple and which they had initially accused of corruption (Anifowose, 2005:191).

However, Aguyi's Ironsi government who took over power from the Balewa's government through coup de-tat on the basis of corruption was later overthrown in July 1966 by General Yakubu Gowon who promised to tackle corruption, but nothing serious was done before he was eventually overthrown. The Muritala/Obasanjo regime who took over power from Gowon attempted to rid Nigeria of this malady which has retarded the nation's development. One of the landmarks recorded was the purged of civil service in 1975 and some rational spending measure introduced in government business to improve the situation. General Obasanjo declaration at Jaji in 1977 showed the commencement of the battle against the creeping culture of corruption, bribery and indiscipline. By the time his regime handed over power to civilian government in 1979 the foreign reserve was quite substantial (Odunuga 2001:69).On October $1^{\text {st }} 1979$ Nigeria returned to civil rule with Alhaji Shehu Shagari as the executive president. The massive financial corruption characterised the government of Shehu Shagari's which took the country into an unprecedented era of debt bondage and economic depression in which is still deeply mired (Familoni 2005). Ajayi (2004, 279-278) remarks of Shagari's regime thus: 
While the First Republic collapsed as a result of factor arising from regional intra-party crisis, the Second Republic collapsed too collapsed under not too different situation. Electoral rigging in 1983 elections instigated by do-a-die winning attitude between the ruling party National Party of Nigeria (NPN) on one hand and the other parties notably Unity Party of Nigeria (UPN) and Nigeria People's Party (NPP) on the other hand caused another military uprising in December 1983. Electoral rigging in opposition states of Ondo, Oyo, Kwara, Imo and Anabram states by the ruling party (NPN) were met with armed confrontation with resultant killings, arson and destruction to property.

Apart from the electoral fraud and crises that characterised Shagari's regime, official corruption was also entrenched in his administration. So bad was the situation that Folarin (2009) remarks of Shagari's administration thus:

The period of ethical revolution was marked by state official amassing wealth from parastatals, board and ministries to stave off as much as possible in an emergent era of "oil doom" (that was a time fortunes on oil revenue had declined considerably) with an interface of inflation and deflation. The Shagari's administration responded by introducing austerity measures, a policy that caused severe social and economic hardships that encourage treasury looting, bribery, fraud and social crimes like robbery. It was this era that witness the phenomenon of arson-after-looting by the officials in a bid offset record that could trace culprits. The Nigeria External Telecommunication (NET) building, among others, was the early victims/examples of this new dimension of corruption.

The continued threats to the nation's stability, corruption and insecurity of lives and property provided the needed justifications for the fourth military intervention in the nation's politics.

The Shagari's regime was overthrown in December 1983 by Buhari/Idiagbon regime's which tried to introduce some discipline by establishing War Against Indiscipline (WAI). WAI was a militant and practical as against theoretical approach pursued by past government to curb the menace of corruption and indiscipline. Setting up military task forces, the "war" range from forcing market prices down, raiding illegal and informal "black market" sale outlets, arresting and detaining corrupt politician, sentencing corrupt offenders to life imprisonment or death; compulsory environmental sanitation, maintenance of decorum at public places, queuing to board buses, trains, planes, to buy stamp at post offices, in making telephone calls, fetching water from public pipe (Folarin 2009). Buhari/Idiagbon's regime mean well for Nigeria, as the polity witness dramatic changes. But the regime was short-lived and lasted for only 20 months. It was overthrown in a coup whose supposedly beneficent leader (Ibrahim Babaginda) said he was to lead country back to democracy (Odunuga 2001).

The historical specificity of the Babaginda regime's was therefore, the transformation of corruption into the ransom d'etre of state power. For example, he enacted the Banks and 
other Financial Institution Decree, No. 24 of 1989, essentially to stop the Central Bank from monitoring oil sales. He also put the Apex Bank under the control of the presidency (Ibrahim 2001). Diamond (1995:443) characterizes Ibrahim Babaginda as the first personal dictator in the country history, obsessed with aggrandizement of his own wealth, power and glory, constantly manipulating the game of democratic transition and the self-interests of the politicians to perpetuate himself in offices. Omotoso (2013) also comments on the situation thus:

This time the military did not willingly relinquish power as in 1979, but for so many reasons which included the crisis generated by the annulment of the June 12, 1993 presidential election believed to have been won by late Chief M.KO Abiola. This singular issue shook the nation to its foundation. The crisis precipitated by Ibrahim Babaginda, the military president who 'dribbled' Nigerians through long-drawn grandiose and elaborate but dubious and cunning policies and programmes designed mainly for self-perpetuation in power and ended up annulling an election adjudged the freest ever.

The Babagida's administration was replaced by Interim Government headed by Ernest Shonekan, this government couldn't achieve anything meaningful before it was overthrown by General Sani Abacha. Abacha's Administration was replica of Babagida's regime; corruption worsened and became a common norm under the Abacha's regime. Agbo (2010:15) re-accounts of Abacha's regimes, when he opines thus:

Under Abacha, shameless corruption and 'area boy diplomacy' reduced the country to a pariah nation. Nigeria became a country with worst rating on the Transparency International Index. By the time Nigeria returned to democracy in1999 an estimated of $\$ 400$ billion of revenue was said have been looted and salted away by different stakeholders in public institution.

There was a startling revelation of gross misuse of public funds after the death of General Sani Abacha. He was alleged to have stashed away some 3.6 billon pound in foreign account. Also his aides were engrossed in various accumulation and impropriety of public funds. His erstwhile security adviser was alleged to have stolen N8.84 billion in forex deals (Ola and Effiong, 1999).

However one would have thought that the death of Abacha would have brought to end the era of corruption in public life. But this was not so, General Abdusalam Abubarka that succeeded Abacha was in power for less than a year and ran up the greatest budget ever in the country's fiscal history. The regime was also in hurry to privatize vital sectors and industries, particularly the refineries and the utility which was shortly resisted by Nigerians, it was clear to discerning Nigerians that it was an attempt by the government to turn the privatization exercise into an instrument of wealth accumulation by a few member of the military elite. However unlike his successor Abubakar kept his promise of handing over powers to a democratic elected government on May 29 1999.The former Nigeria President, 
Olusegun Obasanjo came in at a period in which the nation was already tired of military rule. The continuous rules by the military from 1984 to 1999, a period of nearly sixteen years had brutalized the nation's psyche and left an ogre of corruption and its trail (Familoni, 2005). Olusegun Obasanjo's administration inherited the second most corrupt nation in 1999. Obasajo cited in (Omotoso, 2013) bemoaned the situation he met the nation in, particular as related to the crisis governance. According to him:

We experience in the last decade and half, particularly in the last regime but one, persistent deterioration in the quality of our governance, leading to instability and weakening of all public institutions. Good men were shunned and kept away from government while those who should be kept away were drawn near. Relations between men and women who had been friends for many decades and between communities that had lived together in peace for many generations became very bitter because of actions and inactions of government. The citizen developed distrust in government and because promises made for the improvement of the conditions of the people were not kept, all statements by government met with cynicism. The impact of official corruption is so rampant and has earned Nigeria a very bad image at home and abroad. Besides, it has distorted and retrogressed development. Our infrastructures - NEPA, NITEL, Roads, Railways, Education, Housing and other Social Services were allowed to decay and collapsed. Our country has thus been through one of its darkness periods. All these have brought the nation to a situation of chaos and near despair. This is challenge before us. Fellow Nigerians, let us rise as one, to face the tasks ahead and turn this daunting scene into opportunities in a New dawn. Let us make this the beginning of a genuine Renaissance.

To tackle this problem, that has drawn the nation's development backward, the first bill proposed by the Obasanjo administration after inauguration was the establishment of Independent Corrupt Practice Commission (ICPC) to fight corruption. President Olusegun Obasanjo signed the Anti- corruption bill into law on June 13, 2000, and the Independent Corrupt Practises and Other Related Offences Commission (ICPC) was established and inaugurated in September 2000 with full power to investigate and prosecute reported case of corruption. The ICPC was mandated to prohibit and prescribe punishment for corrupt practices, rid Nigeria of all forms of corruption and related practices and restore the country to enviable standard of respectability and dignity within the comity of nations (Folarin 2009).

Also, the menace of financial and economic crimes which had battered economy and image of the country informed the establishment of Economic and Financial Crimes Commission (EFCC). The legal instrument backing the commission was the EFCC (Established) Act of 2002 with high level support from presidency, legislature and the key security and law enforcement agencies in the country. It focus is to combat financial and economic crimes. The advents of the EFCC and ICPC have marked a turning point in Nigeria's anti-corruption 
crusade since independent (Folarin 2009).

ICPC is an organisation that can be said to have been dead upon arrival. It is inactive, docile, weak and obtuse. It seems not to know its objectives and people's expectation from it. Evidently, the organisation cannot lay much claim to the eradication of corruption in the country. At inception the EFCC really showed commitment and desire to fight corruption but highly controversial. It was controversial in the sense that it later became a potent instrument to intimidate and harass political opponents, particularly of the ruling party (Omotoso, 2013).

According to Alumona (2008:137) consequently, this question becomes pertinent: how has Obasanjo given the forthright, purposeful, committed, honest and transparent leadership he promised in his 1999 inaugural speech? Suffice it to say that this claim flies in the face of so many sordid reports pertaining to corruption whether institutional or personal, in contemporary Nigeria. Examples of cases of corruption in the Fourth Republic include the trial and conviction of former Inspector General of Police, Bode George, former Nigerian Port Authority Board Chairman; former governor of Bayelsa state, D.S.P Alamieyeseigha; former governor of Delta state, James Ibori and host of others. These present crops of politician did not sacrifice anything for the nation's democracy they were only interested in amassing wealth for themselves at the expense of the masses (Shehu, 2017:14). The incidences of corruption and the current revelations and reports of corrupt practices at various level of governments and institutions by EFCC, ICPC and various individual attest to this fact that Nigeria is indeed in a deep governance crises. For instance, the former Nigerian President, Olusegun Obasanjo publicly proclaimed that the National Assembly (the Legislative chamber) is full of rogues and armed robbers. In May 2016, President Buhari openly admitted before the Queen of England the allegation made by the former British Prime Minister, David Cameron that 'Nigeria is fantastically corrupt (Okotoni, 2017). On October 8, 2016, the agents of Department of State Security (DSS) raided the homes of two Supreme Court judges and five other judges overnight, arrested them and recovered large sum of money. The DSS revealed that a total of 15 judges were under investigation over allegation of corruption and also had recovered various sums of money from those arrested including over N93 million and \$530, 000 in cash. A judge of a High Court and his wife were alleged to have collected N597 million bribe between February 20014 and June 2016 (Okotoni, 2017). With these revelations, it is obvious that judiciary that supposed to be the last hope of common man has suddenly become a cesspit of corruption and also contributed immensely to governance crisis in Nigeria. Hence, corruption remains oneof those issues triggering governance crisis in Nigeria and continue to manifest in the all level of governance in the polity.

\section{Conclusion and Policy Recommendations}

In this study, an attempt has been made to situate the history of Nigeria's amalgamation of 1914, within the context of economic exploitation and gains. What informed this project was not to achieve integration, unity and development among the various tribes that later merged together but rather economic interest of British imperialist. As noted earlier, the divide and rule policy of colonial rule reinforced in post-colonial state, leading to mistrust between 
various ethnic groups Thereby, creating divisions among various group in which the country has not able to address even with enormous human and material resources. The conclusion that could be drawn therefore is that the amalgamation of 1914 did not lay a solid foundation for unity and peaceful coexistence among the component units of Nigerians state but rather it sowed the seed of disunity.

Thus, any resolution to the problem of Nigeria must first address the foundational incapacitated amalgamation of 1914. Nigerians must convene a Sovereign National conference devoid of any interferences and manipulation of incumbent government to decide whether to continue with what Lugard established or go separate way. Sovereign National Conference should produce the Nigerian people's constitution which will be the scared document accommodating all diverse ethnic groups in the federation (Adeyemi and Obetoh, 2008). Also the resolution must entail a renegotiation and reinvention of the state along democratic line. Such effort, according to Olukoshi and Agbu must address issues of economic rationality as well as welfare of people. A reconfiguration of the federal state (Nigeria) should entail re-inventing the structure of governance to ensure popular participation, transparency and accountability (Abubakar, 2003). This structure will create unity and peace between different ethnic nationalities and disallow domination of access to political power and national resources by one ethnic group or group of individuals, to achieve this; a responsive leadership of national outlook is needed to bridge the gap created by the past post-independence political leaders between various nationalities that constitutes the Nigerian state. Also Okotoni (2017:52-53) noted that, this restructure also would involve some merger and demerger among various tribe in Nigeria. He gave example of this effort to address this imbalance, merger or demerger in the instance of the Yoruba in Kwara and Kogi States, should be moved to join their kinsmen in the south-western Nigeria, with whom they share cultural affinities. This becomes necessary against the background that the Kwara State created on May 27, 1967 by the Military government of General Yakubu Gowon was made up of the former Ilorin and Kabba Provinces, and was initially named the West Central State, but later changed to Kwara a local name for River Niger. The Yorubas in these states, so addressed as northerners, not only that they have nothing in common whatsoever, they have been marginalised, frustrated and alienated socially, culturally and politically (Okotoni 2017).

In combating corruption at all levels of government and institutions, Nigeria must amend the Penal and Criminal Code (law) which are outdated and drafted over fifty year ago when the country faced lesser crime. The sanctions contained in these laws are insufficient to the offence committed. These laws must be amended in line with the Chinese legal system which lay emphasis on stiffer sanction on corrupt practices. Life imprisonment should melted out on any official who steal above N15 million naira and death penalty for N100 million above. In China where this model is used according to Okotoni 2017, seven thousand and seventy (7070) senior officials were prosecuted from 1992 to 2008, eighteen (18) were executed and another eighteen (18) had their death sentences suspended, while twenty (20) received life sentences. The death penalty law enjoyed overwhelming support by the Chinese as 73 percent of its citizens supported the death penalty in cases of corruption, according to a survey (Kech, 2014). 


\section{Macrothink}

Journal of Public Administration and Governance ISSN 2161-7104 2018, Vol. 8, No. 3

Therefore to address the crisis of governance in Nigeria, the above mention recommendations are way forward to avert the various problems and challenges manifesting in the polity.

\section{References}

Abubakar, D. (2003). The Historical Sociology of the Problem of Nigerian Statehood" in Olaniyan, R. A (ed) The Amagalmation and its Enemies: An Interpretive History of Modern Nigeria, Ile-Ife: Obafemi Awolowo University Press Limited.

Adetoye, D. (2005). The State, Bureaucracy and Corruption in Public Offices in Agagu, A. A and Ola, R. F (eds) Development Agenda of Nigerian State, Ibadan; FIAG (Nigeria) Publisher.

Adeyemi, O. O., \& Obetoh, G. I. (2008). Reconstructing A failed State: A Case of Nigeria in Adeyemo, D., \& Olojede, I. (eds) Reading on Governance and Accountability In Nigeria. Gottingen: Cuvillier Verlag International Scientific Publishers.

Adeyemo, D. O., \& Ihemeje, G. C. (2008). Conceptual Analysis of Accountability and Transparency in Nigeria in Adeyemo, D and Oloyede, I (eds) Reading on Governance and Accountability in Nigeria, Germany: Cuvilier Verlag International Scientific Publisher.

Agagu, A. A. (2004). Nigeria: The Nigerian State Democracy and Development: A Hope Betrayed in Agagu, A. A., \& Ola, R. F. (eds) Development Agenda of Nigerian State, Ibadan; FIAG (Nigeria) Publisher.

Agbo, A. (2010). Institutionalising Integrity Tell Magazine Special Publication: ICPC, Steadily Fulfilling its Mandate, December.

Ajayi, K. (2005). Dimension of Conflict, Crisis Management and Implication for Development in Nigeria in Agagu, A. A., \& Ola, R. F. (eds) Development Agenda of Nigerian State, Ibadan; FIAG (Nigeria) Publisher.

Ake, C. (1996) Democracy and Development in Africa, Washington D, C: African Books Collective Publishers.

Akindele, S. T., Obiyan, A. S., \& Owoeye, J. (2000). The Subject Matter of Political Science, Ibadan: College Press \& Publishers Ltd.

Akinjide, R. (2000). National Question The Guardian Newspaper, September 2.

Akinjide, R. (2001). Amalgamation the Comet, July 9.

Akinola, O. (2013). Governing Nigeria 100 Years after Amalgamation: From a 'Mistake' to Miracle? Accessed at http://papers.ssrn.com/sol3/papers.cfm.

Alanamu, A. S., Yinusa, M. A., \& Adeoye, M. N. (2008). Corruption and its Implication for National Development under the Fourth Republic in Saliu, H. A., Jimoh, I. J., Yusuf, N., \& Ojo, E. O. (eds) Perspective on Nation-Building and Development in Nigeria: Political and Legal Issues, Lagos: Concept Publication Limited

Alumona, V. S. (2003). The Rhetoric of Corruption and the Quest for Political Power in 
Nigeria in Babawale, T., \& Olukoya, O. (eds) Culture and Society in Nigeria: Popular Culture, Language and Intergroup Relations, Lagos: Concept Publication Limited.

Amobi, P., Chiamogu1, A. P., Onwughalu, V. C., \& Chiamogu, U. P. (2011). Politics of Inter-Governmental Relations in Nigeria: An Appraisal of Current Issues" accessed at http://www.aessweb.com/journal

Anifowose, R. (2005). Conclusion and Summary Remarks in Olurode, L., \& Anifowose, R. (eds) Rich But Poor, Corruption and Good Governance in Nigeria, Lagos: Faculty of Social Science, University of Lagos.

Anifowose, R. (2008). State, Society and Nation in Anifowose, R., \& Enemuo, F. (eds) Element of Politics, Lagos: Sam Iroanusi Publications

Bangura, Y. (1988). The Crisis of Underdevelopment and the Transition to Civil Rule: Conceptualising the Question of Democracy in Nigeria, African Development, 8(1).

Bevir, M. (2013). Governance: A very short introduction, Oxford, UK: Oxford University Press.

Diamond, L. (1995). Nigeria's Uncivil Society and Descent into Praetorianism" in Diamond, L., Linz, J., \& Lipset (eds) Politics in Developing Countries: Comparing Experiences with Democracy, $2^{\text {nd }}$ Edition, Boulder: Lynne Rienner.

Europa (No Date) accessed at http://ec.europa.eu/governance/docs/doc5_fr.pdf

Ezeibe, (No Date). Inter-Religious Conflicts And Crisis Of Development In Nigeria: Who Benefits? accessed at http://www.academicexcellencesociety.com/inter_religious_...

Familoni, K. (2005). Political Economy of Corruption in Olurode L. And Anifowose, R. (eds) Rich But Poor, Corruption and Good Governance in Nigeria, Lagos: Faculty of Social Science, University of Lagos.

Fawole, W. L. (2003). Military Rule and the Unitarianization of Nigeria in Olaniyan, R. (ed) The Amagalmation and its Enemies: An Interpretive History of Modern Nigeria, Ile-Ife: Obafemi Awolowo University Press Limited.

Folarin, S. (2009). The Anti- Corruption War in Nigeria: A Critical Appraisal of The Role of ICPC and EFCC", Nigerian Journal of Economic and Financial Crimes, 1(2), January April, Abuja.

Ihonvbere. (1996). A Radical View of Nigeria's Political Development, in Oyediran, O. (eds) Governance and Development in Nigeria: Essays in Honour of Billy Dudley, Ibadan: Oyediran Consult International Publisher.

Jega, A. (1999). Governance and Nigerian Economy in Governance and Nigerian Economy: Proceeding of the one day Seminar held on January 19, 1994. First published in 1999 by The Nigerian Economy Society (NES).

Kech, Z. K. (2014). China Overwhelming Supports Death Penalty for Corrupt Official” The 
Diplomat,

accessed 2018, Vol. 8, No. 3

http://thediplomat.com/2014/11/china-overwhelmingly-supports-death-penalty ....

Khan, M. H. (2004). State Formation in Palestine: Viability and Governance During a Social Transformation: Volume 2 of Political economy of the Middle East and North Africa: Routledge

Kolawole, D. (2004). Nigeria: The Struggle for Democratic Consolidation in Post- Colonial" in Agagu, A. A and Ola, R. F (eds) Development Agenda of Nigerian State, Ibadan; FIAG (Nigeria) Publisher.

Mamdani, M. (1996). Citizen and Subject: Contemporary Africa and Legacy of Late Colonialism, Princeton: Princeton University Press.

Odunuga, S. (2001). The Impact of Corruption and Organized Crime in Nigeria's Economy and Economic Development", in Ibrahim L and Odekunle (eds) Fighting Corruption and Organized Crime in Nigeria: Challenges for the New Millennium, Ibadan: Spectrum Books limited.

Ohchr (No Date) accessed at http://www.ochr.org/en/Issues/Development/Good/GovernmentIdex.aspx)

Okotoni, M. A. (2017). Governance Crisis and State Failure in Nigeria: Are We All Guilty? An Inaugural Lecture Delivered at Oduduwa Hall, Obafemi Awolowo University, Ile-Ife, Nigeria, on $14^{\text {th }}$ March, 2017.

Ola, R. O. F., \& Effiong, O. J. (1999). Public Finance Management in Nigeria, Lagos: Anifitop Books.

Omotoso, F. (2013). Governance Crisis and Democracy in Nigeria, 1999-2012" Mediterranean Journal of Social Sciences Vol. 4, No 14, November, MCSER Publishing, Rome-Italy. https://doi.org/10.5901/mjss.2013.v4n14p125

Shehu, A. Y. (2006). Economic and Financial crimes in Nigeria: Policy Issues and Options, Lagos: National Open University of Nigeria.

Shehu, S. (2017). Shehu Sani Tackle Obasanjo over Failure to Honour MKO” The Punch Newspaper, June 13.

Unescap (No Date) What is Good Governance? Accessed at (http://www.unescap.org/site/default/file/good-governance.pdf)

World Bank (1992). Governance and Development”. International Bank for Reconstruction and Development (IBRD), Washington, D.C

World Bank (No Date) accesses at (http://web.worldbank.org/WBSITE/EXTERNAL...) 


\section{Copyright Disclaimer}

Copyright for this article is retained by the author(s), with first publication rights granted to the journal.

This is an open-access article distributed under the terms and conditions of the Creative Commons Attribution license (http://creativecommons.org/licenses/by/4.0/). 